\title{
NURSING STUDENTS APPROACH TO LEARNING: DEVELOPING A RESEARCH QUESTION FROM THE EVIDENCE
}

\author{
Pendekatan Belajar Siswa Keperawatan: Merumuskan Sebuah Pertanyaan Penelitian \\ melalui Bukti Penelitian
}

Edi Purwanto

${ }^{1}$ School of Nursing, Faculty of Health Sciences, University of Muhammadiyah Malang

${ }^{2}$ Email: purwa_edi@umm.ac.id

\begin{abstract}
There were two $f$ student's approaches to learning were identified: a deep approach and a surface approach. Based on intrinsic interest in the topic, students taking a deep approach try to understand ideas and seek meaning and understanding. There was no published research regarding assessing student learning process related to problem-based learning in Indonesia. The study will be a significant endeavour in motivating and supporting nursing lecturer in order to evaluating nursing student approaches to learning. This study will be an important contribution to the body of knowledge concerning on students learning method in problem-based learning approach. The research may also serve useful reference tool for future studies especially in Indonesia context. This was a quantitative research question since the outcome was going to investigate undergraduate nursing students' approaches to learning and academic achievement in problem-based learning context in Indonesia.
\end{abstract}

Keywords: Nursing, students' approach to learning, problem-based learning

\begin{abstract}
ABSTRAK
Jenis pendekatan siswa dalam belajar diidentifikasi: pendekatan dalam dan pendekatan permukaan. Berdasarkan kepentingan intrinsik dalam topik, siswa mengambil pendekatan yang mendalam dengan mencoba memahami ide-ide dan mencari makna dan pemahaman. Tidak ada penelitian yang dipublikasikan mengenai penilaian proses belajar siswa yang berkaitan dengan pembelajaran berbasis masalah di Indonesia. Studi ini akan menjadi cara yang signifikan dalam memotivasi dan mendukung dosen keperawatan untuk mengevaluasi mahasiswa keperawatan dengan pendekatan pembelajaran. Penelitian ini akan menjadi kontribusi penting untuk pengetahuan siswa tentang metode pendekatan pembelajaran berbasis masalah. Penelitian ini juga dapat berfungsi alat referensi yang berguna untuk studi masa depan terutama dalam konteks Indonesia. Ini adalah pertanyaan penelitian kuantitatif karena hasilnya akan menyelidiki pendekatan sarjana mahasiswa keperawatan 'untuk belajar dan prestasi akademik di berbasis masalah konteks pembelajaran di Indonesia.
\end{abstract}

Kata kunci : Keperawatan, pendekatan siswa dengan belajar, pembelajaran berbasis masalah

\section{INTRODUCTION}

According to Trigwell (2005), varieties of student's approaches to learning were identified: a deep approach and a surface approach. Based on intrinsic interest in the topic, students taking a deep approach try to understand ideas and seek meaning and understanding. Whereas, students who use a surface approach tend to see superficially the teacher's task. One form of teaching process which has been applied in several health science schools was Problem-Based Learning (PBL). Hamilton 1976, Neufeld and Barrows 1974 (cited Gwee, M.C 2008; Schmidt 2012) 
stated that the first problem-based learning (PBL) was implemented by Faculty of Health Science, McMaster University, Canada in 1969. It then spread across the world including Indonesia. International Medical School Program, University of Gadjah Mada (UGM) in Indonesia has begun the first problem based-learning in 2002. Six years later, Ministry of National Education, Indonesia has introduced problem based-learning approach in higher education especially in health science school. Thus, one of the biggest private universities in East Java, School of Nursing University of Muhammadiyah Malang (UMM) has started using problem-based learning (PBL) in 2010. This program might changes learning paradigms which are teacher centre-learning to student centre-learning. The changes will affect several challenges such as curriculum, timetabling, staff development, physical infrastructure, students' attitude, student learning methods and student assessments to support this program (Yew \& O'Grady 2012).

While studies on students' approaches to learning and PBL have been researched globally, there was no published research regarding assessing student learning process related to problem-based learning in Indonesia. Therefore, it is important to examine first the Indonesian undergraduate nursing students' approaches to learning in problem-based learning context. These articles describe how to locate the evidence using several databases resources related with the research question using PICO framework. There are some resources which can be used; they are
Cochrane, Joanna Briggs, CINAHL, PubMed, ProQuest and IJPBL.

\section{METHOD}

\section{Databases}

The first step was finding database

on Flinders Library
(http://multisearch.flinders.edu.au:8331/V/? func=find-db-1). The second step was to open the name of databases which can be used to develop the research question: CINAHL, Elsevier, Cochrane, Joanna Briggs, ProQuest, Expanded Academic ASAP (Gale), PubMed Queries Database and IJPBL. The author focused on the studies which are researched on students' approaches to learning and problem-based learning. Then, using keywords search in searching engine in the database "problembased learning" and "students' approaches to learning" to find studies related with the initial research question.

\section{RESULT AND DISCUSSION}

a) CINAHL database

The first database was Cumulative Index Nursing and Allied Health Literature (CINAHL) database which is nursing and allied databases in the USA. Then, several limitations was applied to make it more specific and relevant, e.g. linked full text, references available, abstract available, date published. Moreover, combinations of key words were used to find results related to the topic. The steps for obtaining relevant articles presented in the table below:

\begin{tabular}{llll}
\hline Code & Keywords search terms & Limitations & Number of hits \\
\hline S1 & "learning approach" & All results & 276 \\
\hline & Linked full text & 5 \\
& References available \\
& Abstract available \\
& Published 2003-2013 \\
\hline
\end{tabular}




\begin{tabular}{|c|c|c|c|}
\hline S2 & "students' approach" & $\begin{array}{l}\text { All results } \\
\text { Published 2003-2013 }\end{array}$ & 17 \\
\hline S3 & "students' approach" & $\begin{array}{l}\text { Linked full text } \\
\text { References available } \\
\text { Abstract available } \\
\text { Published 2003-2013 }\end{array}$ & 3 \\
\hline S4 & $\begin{array}{l}\text { "problem-based } \\
\text { learning" }\end{array}$ & $\begin{array}{l}\text { All results } \\
\text { Published 2003-2013 }\end{array}$ & 1472 \\
\hline & "approaches to learning" & $\begin{array}{l}\text { All results } \\
\text { Published 2003-2013 }\end{array}$ & 40 \\
\hline S5 & "approaches to learning" & $\begin{array}{l}\text { Linked full text } \\
\text { References available } \\
\text { Abstract available } \\
\text { Published 2003-2013 }\end{array}$ & 2 \\
\hline S6 & $\begin{array}{l}\text { "problem-based } \\
\text { learning" AND } \\
\text { "approaches to learning" }\end{array}$ & $\begin{array}{l}\text { Linked full text } \\
\text { References available } \\
\text { Abstract available } \\
\text { Published 2003-2013 }\end{array}$ & 5 \\
\hline
\end{tabular}

Regarding to the table, the author first found 276 articles. After refining process, 5 articles were retrieved. However, only 1 article was chosen as the best articles which provide lots of information to explore more understanding about the topic.

b) Elsevier (SciVerse ScienceDirect)
The second database was Elsevier (SciVerse ScienceDirect) which was a multidisciplinary index to the journal literature of the sciences, social sciences, arts and humanities. The steps for obtaining relevant articles presented in the table below:

\begin{tabular}{|c|c|c|c|}
\hline Code & Keywords search terms & Limitations & Number of hits \\
\hline S1 & $\begin{array}{l}\text { "Students approaches to } \\
\text { learning" }\end{array}$ & - $\quad$ All results & 13.603 \\
\hline $\mathbf{S 2}$ & $\begin{array}{l}\text { "students approaches to } \\
\text { learning" AND "problem- } \\
\text { based learning" }\end{array}$ & - Journals: nursing and health professional & 8,725 \\
\hline S3 & $\begin{array}{l}\text { "students approaches to } \\
\text { learning" AND "problem- } \\
\text { based learning" }\end{array}$ & $\begin{array}{l}\text { - Journals: nursing and health professional } \\
\text { - } \quad \text { Published 2003-2013 }\end{array}$ & 4958 \\
\hline S4 & $\begin{array}{l}\text { "students approaches to } \\
\text { learning" AND problem- } \\
\text { based learning" }\end{array}$ & $\begin{array}{l}\text { - Journals: nurse education today, journal of } \\
\text { professional nursing, teaching and learning in } \\
\text { nursing, international journal of nursing Studies, } \\
\text { AORN Journal } \\
\text { - Topics: nursing student, nursing education, nurse } \\
\text { education, nursing, student, critical thinking, } \\
\text { undergraduate nursing, nursing program } \\
\text { - Published 2003-2013 }\end{array}$ & 640 \\
\hline S5 & $\begin{array}{l}\text { "students approaches to } \\
\text { learning" AND "problem- } \\
\text { based learning" }\end{array}$ & $\begin{array}{l}\text { - Journals: nurse education today, teaching and } \\
\text { learning in nursing, } \\
\text { - Topics: nursing student, nursing education, nurse } \\
\text { education, nursing, student, critical thinking, } \\
\text { undergraduate nursing, nursing program } \\
\text { - Published 2003-2013 }\end{array}$ & 55 \\
\hline
\end{tabular}


c) The Cochrane Library

This database was a systematic review in health care which focused on the effectiveness of health-care interventions
(Craig \& Smith 2007, p. 62). The steps for obtaining relevant articles presented in the table below:

\begin{tabular}{|c|c|c|c|}
\hline Code & Keywords search terms & Limitations & Number of hits \\
\hline \multirow[t]{2}{*}{ S1 } & "learning approach" & All results & 769 \\
\hline & & $2003-2013$ & \\
\hline \multirow[t]{2}{*}{$\mathbf{S 2}$} & "approaches to learning" & All results & 756 \\
\hline & & $2003-2013$ & \\
\hline \multirow[t]{2}{*}{ S3 } & "approaches to learning" & Trials & 676 \\
\hline & & $2003-2013$ & \\
\hline \multirow[t]{2}{*}{ S4 } & "problem-based learning" AND "approaches to learning" & Published & 101 \\
\hline & & $2003-2013$ & \\
\hline \multirow[t]{2}{*}{ S5 } & "problem-based learning" AND "approaches to learning" & Trials & 90 \\
\hline & & $2003-2013$ & \\
\hline \multirow[t]{2}{*}{ S6 } & problem-based learning" & Published & 10 \\
\hline & learning" AND “nursing” & $2003-2013$ & \\
\hline \multirow[t]{2}{*}{ S7 } & problem-based learning" & Trials & 8 \\
\hline & learning" AND “nursing” & & \\
\hline
\end{tabular}

d) The Joanna Briggs

According to Craig and Smyth (2007, p. 61), this Australian database presents "summaries of best practices for a variety of clinical topics relevant to nursing". The steps for obtaining relevant articles presented in the table below:

\begin{tabular}{lllc}
\hline Code & Keywords search terms & Limitations & Number of hits \\
\hline S1 & "problem-based learning" & $\begin{array}{l}\text { All results } \\
\text { Published 2003 -2013 }\end{array}$ & 11 \\
\hline S2 & "problem-based learning AND "nursing" & $\begin{array}{l}\text { All results } \\
\text { Published 2003 -2013 }\end{array}$ & 10 \\
\hline S4 & $\begin{array}{l}\text { "problem-based learning" AND } \\
\text { "nursing" AND "student approaches to } \\
\text { learning" }\end{array}$ & $\begin{array}{l}\text { Systematic reviews } \\
\text { Published 2003 -2013 }\end{array}$ & 0 \\
\hline
\end{tabular}

e) ProQuest database

The steps for obtaining relevant articles presented in the table below:

\begin{tabular}{|c|c|c|c|}
\hline Code & Keywords search terms & Limitations & $\begin{array}{l}\text { Number of } \\
\text { hits }\end{array}$ \\
\hline S1 & $\begin{array}{l}\text { "students' approaches to } \\
\text { learning" AND "problem- } \\
\text { based learning" }\end{array}$ & - $\quad$ All results, full text, peer reviewed & 136289 \\
\hline S2 & $\begin{array}{l}\text { "students' approaches to } \\
\text { learning" AND "problem- } \\
\text { based learning" }\end{array}$ & $\begin{array}{l}\text { - All results, full text, peer reviewed, } \\
\text { published 2003-2013 }\end{array}$ & 130735 \\
\hline S3 & approaches & - $\quad$ Scholarly journals, report, conference paper & 88803 \\
\hline
\end{tabular}




\begin{tabular}{|c|c|c|c|c|}
\hline & $\begin{array}{l}\text { learning" AND "problem- } \\
\text { based learning" }\end{array}$ & & $\begin{array}{l}\text { and proceeding, evidence based medical } \\
\text { resources, Published 2003-2013 }\end{array}$ & \\
\hline S4 & $\begin{array}{l}\text { "students' approaches to } \\
\text { learning" AND "problem- } \\
\text { based learning" }\end{array}$ & $\bullet$ & $\begin{array}{l}\text { Publication title: Journal of nursing } \\
\text { education, School Psychology Review, } \\
\text { Nursing Education Perspectives, English } \\
\text { Journal, Innovations in Education and } \\
\text { Teaching International, Creative Education, } \\
\text { American Educational Research Journal, } \\
\text { The Journal of Educational Research } \\
\text { Published 2003-2013 }\end{array}$ & 2102 \\
\hline S5 & $\begin{array}{l}\text { "students' approaches to } \\
\text { learning" AND "problem- } \\
\text { based learning" }\end{array}$ & • & $\begin{array}{l}\text { Publication title: Journal of nursing } \\
\text { education, Nursing Education Perspectives } \\
\text { Published 2003-2013 }\end{array}$ & 856 \\
\hline S6 & $\begin{array}{l}\text { "students' approaches to } \\
\text { learning" AND "problem- } \\
\text { based learning" }\end{array}$ & $\bullet$ & $\begin{array}{l}\text { Document type: article } \\
\text { Published 2003-2013 }\end{array}$ & 800 \\
\hline S7 & $\begin{array}{l}\text { "students' approaches to } \\
\text { learning" AND "problem- } \\
\text { based learning" }\end{array}$ & & $\begin{array}{l}\text { Subject : nursing education } \\
\text { Published 2003-2013 }\end{array}$ & 290 \\
\hline S8 & $\begin{array}{l}\text { "students' approaches to } \\
\text { learning" AND "problem- } \\
\text { based learning" }\end{array}$ & • & $\begin{array}{l}\text { Subject: nursing education, document type: } \\
\text { article, } \\
\text { Published 2009-2013 }\end{array}$ & 161 \\
\hline S9 & $\begin{array}{l}\text { "students' approaches to } \\
\text { learning" AND "problem- } \\
\text { based learning" }\end{array}$ & $\bullet$ & $\begin{array}{l}\text { Subject: nursing education, document type: } \\
\text { article, published 2011-2013 }\end{array}$ & 85 \\
\hline
\end{tabular}

\section{f) Expanded Academic ASAP (Gale)}

The steps for obtaining relevant articles presented in the table below:

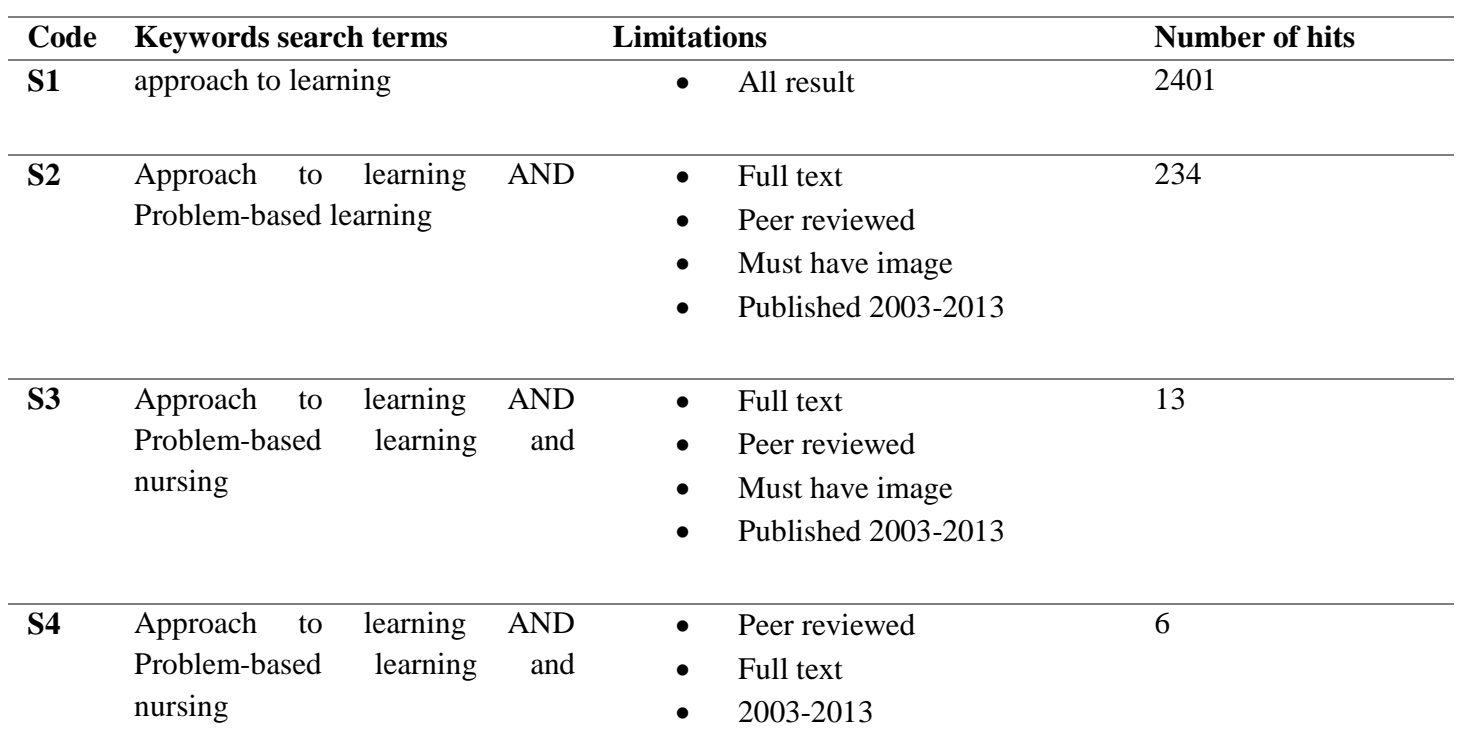


g) PubMed Clinical Queries Database

The database was developed by the National Centre for Biotechnology Information at the US National Library of Medicine (Craig \& Smyth 2007, p. 66). The steps for obtaining relevant articles presented in the table below:

\begin{tabular}{|c|c|c|c|}
\hline Code & Keywords search terms & Limitations & $\begin{array}{c}\text { Number } \\
\text { of hits }\end{array}$ \\
\hline S1 & $\begin{array}{l}\text { "problem-based learning } \\
\text { nursing" }\end{array}$ & - $\quad$ All results & 1315 \\
\hline $\mathbf{S 2}$ & $\begin{array}{l}\text { "problem-based learning } \\
\text { nursing" }\end{array}$ & $\begin{array}{l}\text { - Case report, comparative study, evaluation study, } \\
\text { systematic review, } \\
\text { - Publication dates }=10 \text { years. }\end{array}$ & 974 \\
\hline S3 & $\begin{array}{l}\text { "problem-based learning } \\
\text { nursing" }\end{array}$ & 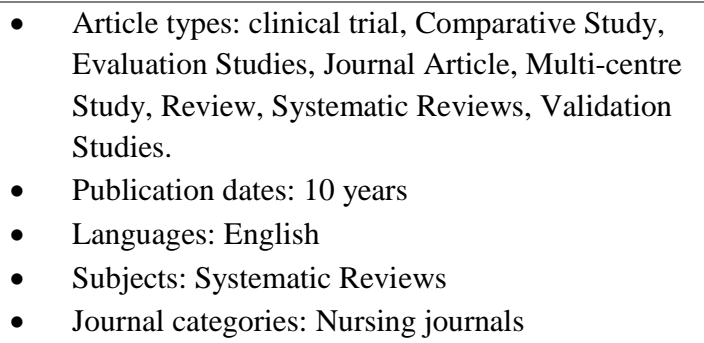 & 705 \\
\hline $\mathbf{S 4}$ & $\begin{array}{l}\text { "problem-based learning } \\
\text { nursing" AND "students' } \\
\text { approaches to learning" }\end{array}$ & $\begin{array}{l}\text { - } \\
\text { Article types: clinical trial, Comparative Study, } \\
\text { Evaluation Studies, Journal Article, Multi-centre } \\
\text { Study, Review, Systematic Reviews, Validation } \\
\text { Studies. } \\
\text { - } \quad \text { Publication dates: } 10 \text { years } \\
\text { - } \quad \text { Languages: English } \\
\text { - } \quad \text { Subjects: Systematic Reviews } \\
\text { - } \quad \text { Journal categories: Nursing journals }\end{array}$ & 13 \\
\hline
\end{tabular}

h) Interdisciplinary professional problembased learning (IJPBL)

The last database was the Interdisciplinary Journal Of Problem-Based Learning (IJPBL). When the author tried to find using keyword "problem-based learning" at Flinders University website, the author got that http://www.flinders.edu.au/teaching/quality /teaching-methods/problem-based-

learning.cfm. This site recommends some resources about problem-based learning. One of the sites is the Interdisciplinary Journal of Problem-Based Learning (IJPBL) which is an accessible journal relates on practice and research of problembased learning.

\begin{tabular}{|c|c|c|c|c|}
\hline Code & Keywords search term & & Limitations & Number of hits \\
\hline S1 & "learning approach" & & - $\quad$ All results & 66 \\
\hline $\mathbf{S 2}$ & $\begin{array}{l}\text { "learning approach" } \\
\text { "problem-based learning" }\end{array}$ & AND & - $\quad$ All results & 66 \\
\hline S3 & $\begin{array}{l}\text { "learning approach" } \\
\text { "problem-based learning" } \\
\text { "nursing" }\end{array}$ & $\begin{array}{l}\text { AND } \\
\text { AND }\end{array}$ & - $\quad$ Published 2008-2013 & 17 \\
\hline S4 & approach" & AND & - $\quad$ Published 2008-2013 & 10 \\
\hline
\end{tabular}


Finally, from all of the databases used for literature searching, ten articles were chosen as they were considered as the most relevant to the initial research question. Articles were included on the basis that nursing students were in the main population of the study.

There were ten articles found which were considered as the most relevant with the initial research question. Generally, the aims of the studies were to find out the best approaches to study in the educational and practical nursing. The methods of studies were 6 quantitative approaches, 1 quasi experiment, 2 qualitative method and 1 mixed method. Most of samples of the studies were nursing students and two of them were law students and health science. The result of studies was self-active learning which provided in deep approaches than instructional learning. Majority of the studies had limitations in small number of samples, no group of control. Therefore, further study is needed. The significance and recommendation were longitudinal design; developing research instrument and follow up would also help indicate whether learning approaches was sustained over time.

In problem-based learning, students learned together with others on clinical problems or related topic and guided by facilitator. The purposes of PBL approaches are allowed student to have analysis the problem, independent study, interdisciplinary subject study, collaboration and solve the problem (Savery 2006). In order to be able to achieve these aims, students were encouraged to have a good self-learning approach. Their ability to independent study was influenced by the way of student's approaches to learning. Revised two-factor study process questionnaire (RSPPQ-2F) may appropriate evaluates critical thinking nursing students on problem-based learning approaches (Biggs et al. 2001). Academic achievements here could be represented by the student's ability to solve a problem, i.e. case study, which portrays the student's critical thinking. Critical thinking of student could be addressed by PBL (Applin et al. 2010). This learning approach supports contextualisation of knowledge essential to nursing practice. As the final outcomes of PBL, student are encouraged to be able to use their critical thinking to apply their problem solving and reasoning skills (Applin et al. 2010). Some researchers had addressed this issue in Japan (Fryer et al. 2012), Netherland (Stes et al. 2013), and China (Taher et al 2011). They believed that there is a relationship between students' learning approaches and their academic achievement (Taher et al 2011; Fryer et al. 2012; Stes et al. 2013).

There was no published research regarding assessing student learning process related to problem-based learning in Indonesia. The study will be a significant endeavour in motivating and supporting nursing lecturer in order to evaluating nursing student approaches to learning. This study will be an important contribution to the body of knowledge concerning on students learning method in problem-based learning approach. The research may also serve useful reference tool for future studies especially in Indonesia context. 
Therefore, the research question is that how are undergraduate nursing students' approaches to learning and academic achievement in problem-based learning context in Indonesia?

\section{CONCLUSION}

In brief, there is a shift of initial question which is now more specific after locating the evidence from computerised literature search. The computer searches consisted primarily from eight databases: CINAHL, Elsevier, Cochrane, Joanna Briggs, ProQuest, Gale, PubMed and IJPBL. There were limitations set for searches consisted of source type, publication years, specific database, languages and document type. The key search terms included 'students' approaches to learning", "problem-based learning" and "nursing". There were ten studies retrieved which were relevant with the research question. Finally, a new research question has been drawn using PICO framework. This was a quantitative research question since the outcome was going to investigate undergraduate nursing students' approaches to learning and academic achievement in problem-based learning context in Indonesia

\section{REFERENCES}

Applin, H, Williams, B, Day, R, \& Buro, K 2011, 'A comparison of competencies between problembased learning and non-problembased graduate nurses', Nurse Education Today, vol. 31, pp. 129-134, viewed 13 March 2013 , (online SciVerse ScienceDirect Journals).

Biggs, J, Kember, D, \& Leung DY.P 2001, 'The revised two-factor study process questionnaire: RSPQ-2F', British Journal Of Educational Psychology, vol. 71, pp. 133-149, viewed 13 March 2013, (online Bell \& Howell/ProQuest Central).

Fryer, LK, Ginns, P Walker, R.A \& Nakao, K. 2013, 'The adaptation and validation of the CEQ and the R-SPQ-2F to the Japanese tertiary environment', British Journal of Educational Psychology, vol. 82, pp. 549-563, viewed 13 March 2013 , (online Wiley Interscience/Cochrane Database of systematic review).

Craig, JV \& Smyth, RL 2007, The Evidence-Based Practice Manual for Nurses, $3^{\text {rd }}$ edn, Churchill Livingstone, Edinburgh.

Gwee, MCE 2008, 'Globalization of problem-based learning (PBL): cross-cultural implications', Kaohsiung J Med Science, vol. 24, No. 2, pp. 14-22, viewed 13 March 2013, (online Elsevier/Science Direct).

Savery, JR. 2006, 'Overview of Problem-based Learning: Definitions and Distinctions', Interdisciplinary Journal of Problem-based Learning, vol. 1, no. 1 , viewed 13 March 2013, (Online Elsevier/Science Direct).

Stes, A Maeyer SD \& Petegem, PV 2013, 'Examining the CrossCultural Sensitivity of the Revised Two-Factor Study Process 
Questionnaire (R-SPQ-2F) and Validation of a Dutch Version', PLOS ONE, vol. 8, no. 1, viewed 13 March 2013, <www.plosone.org>.

Schmidt, H.G, 2012 'A Brief History of Problem-based Learning', in OneProblem: An Approach to Problem-based Learning, eds O'Grady, G Yew, E.H.J, Goh, K.P.L \& Schmidt, H.G, Springer Singapore.

Yew, EHJ and Glen O'Grady, G 2012 'A Brief History of Problembased Learning', in One-Problem: An Approach to Problem-based Learning, eds O'Grady, G Yew, E.H.J, Goh, K.P.L \& Schmidt, H.G, Springer Singapore.

Taher, A.M.M, Hand and Jin, C 2011, 'Assessing learning approaches of Chinese local MBA students: An investigation using the Revised Two factor Study Process Questionnaire (R-SPQ-2F)', Educational Research and Reviews, vol. 6, no. 19, pp. 974978, viewed 13 March 2013, (online Bell \& Howell/ProQuest Central).

Trigwell K, Prosser M, \& Ginns P 2005, 'Phenomenographic pedagogy and a revised approaches to teaching inventory', Higher Education Research and Development, vol. 24, pp. 349360, viewed 13 March 2013, (online Bell \& Howell/ProQuest Central). 